\title{
KYPHECTOMY IN PATIENTS WITH MYELOMENINGOCELE: SURGICAL RESULTS AND COMPLICATIONS
}

\author{
CIFOSECTOMIA EM PACIENTES COM MIELOMENINGOCELE: \\ RESULTADOS CIRÚRGICOS E COMPLICAÇÕES
}

\author{
CIFOSECTOMÍA EN PACIENTES CON MIELOMENINGOCELE: \\ RESULTADOS QUIRÚRGICOS Y COMPLICACIONES
}

Pedro Araujo Petersen', Romero Pinto de Oliveira Bilhar ${ }^{1}$, Raphael Martus Marcon ${ }^{1,2}$, Olavo Biraghi Letalf ${ }^{1,2}$, Marcus Alexandre Mello Santos²,

Tarcísio Eloy Passos de Barros Filho ${ }^{1}$, Alexandre Fogaça Cristante ${ }^{1,2}$

\begin{abstract}
Objectives: The lumbar kyphosis in patients with myelomeningocele is a complex deformity whose treatment is mainly surgical. The objective of this study is to summarize the results and complications obtained by the group in 2012 with respect to this group of patients. Method: Performed a retrospective analysis of the medical records and radiographs of patients consecutively operated in 2012 . The technique was originally described by Dunn-McCarthy and consists of kyphectomy and posterior fixation using S-shaped Luque rods through the foramina of S1 associated with pedicle screws in the thoracic spine. Results: Six patients were included in the study. The age at surgery was 11 years and $7 \pm 22$ months and the weight was $29.1 \pm 11.9 \mathrm{~kg}$. The procedure lasted $271 \pm 87$ minutes, with the removal of one or two (mean 1.5) vertebrae from the apex of the kyphosis. Hospitalization time was $10 \pm 9$ days. The lumbar kyphosis measuring $116.3 \pm 37$ degrees preoperatively was reduced to $62.5 \pm 21$ degrees. All patients began to sit without support and to lie in the supine position. Four patients developed postoperative infection and required surgical debridement at the follow-up. One patient had the implant removed after a year due to loosening of the rod in the sacrum. Conclusion: The surgical technique allows excellent functional results in the correction of lumbar kyphosis in patients with myelomeningocele despite high complication rates. It is necessary to conduct studies with a larger number of patients and duration of follow-up to assess whether the use of pedicle screws will decrease the rate of loosening and pseudoarthrosis.
\end{abstract}

Keywords: Myelomeningocele; Pedicle screws; Kyphosis; General surgery; Postoperative complications.

\section{RESUMO}

Objetivos: A cifose lombar em pacientes com mielomeningocele é uma deformidade complexa cujo tratamento é eminentemente cirúrgico. O objetivo deste estudo é resumir os resultados e complicações obtidos pela equipe, em 2012, com relação a esse grupo de pacientes. Método: Foi feita análise retrospectiva dos prontuários e radiografias de pacientes operados consecutivamente em 2012. A técnica utilizada foi descrita originalmente por Dunn-McCarthy e consiste em cifosectomia e fixação posterior utilizando-se hastes moldadas em "S" através dos forames de S1 associados a parafusos pediculares na coluna torácica. Resultados: Foram incluídos seis pacientes no estudo. A idade à realização da cirurgia foi de 11 anos e $7 \pm 22$ meses e o peso foi 29,1 $\pm 11,9 \mathrm{~kg}$. O procedimento durou $271 \pm 87$ minutos, com a retirada de uma ou duas (média de 1,5) vértebras do ápice da cifose. O tempo de internação foi de $10 \pm 9$ dias. A cifose lombar que media 116,3 \pm 37 graus no pré-operatório foi reduzida para 62,5 \pm 21 graus. Todos os pacientes passaram a sentar sem apoio e a deitar na posição supina. Quatro pacientes evoluíram com infecção pós-operatória e necessitaram de limpeza cirúrgica no seguimento. Um paciente teve o implante retirado após um ano, devido à soltura da haste no sacro. Conclusão: A técnica cirúrgica utilizada permite resultados funcionais excelentes na correção da cifose lombar em pacientes com mielomeningocele, apesar das altas taxas de complicações. É preciso realizar estudos com maior número de pacientes e tempo de seguimento para se avaliar se a utilização de parafusos pediculares diminuirá a taxa de soltura e pseudoartrose.

Descritores: Mielomeningocele; Parafusos pediculares; Cifose; Cirurgia geral; Complicações pós-operatórias.

\section{RESUMEN}

Objetivos: La cifosis lumbar en pacientes con mielomeningocele es una deformidad compleja cuyo tratamiento es principalmente quirúrgico. El objetivo de este estudio es resumir los resultados y complicaciones obtenidos por el equipo en 2012, con respecto a este grupo de pacientes. Método: Se realizó un análisis retrospectivo de las historias clínicas y las radiografías de los pacientes intervenidos consecutivamente en 2012. La técnica fue descrita originalmente por Dunn-McCarthy y constituye en cifosectomía y fijación posterior con los tallos en forma de "S" a través de los forámenes de S1 asociados con tornillos pediculares en la columna torácica. Resultados: Se incluyeron 6 pacientes en el estudio. La edad a la cirugía fue de 11 años y $7 \pm 22$ mmeses y el peso fue 29,1 $\pm 11,9 \mathrm{~kg}$. El procedimiento duró $271 \pm 87$ minutos, con la eliminación de una o dos (media 1,5) vértebras desde el ápice de la cifosis. El tiempo de hospitalización fue de $10 \pm 9$ días. La cifosis lumbar midiendo 116,3 \pm 37 grados antes de la operación se redujo a 62,5 \pm 21 grados. Todos los pacientes empezaron a sentarse sin apoyo y acostarse en la posición supina. Cuatro pacientes desarrollaron infección postoperatoria y requirieron limpieza quirúrgica en el seguimiento. Un paciente tuvo el implante retirado después de un año debido al aflojamiento del tallo en el sacro. Conclusión: La técnica quirúrgica utilizada permite excelentes resultados funcionales en la corrección de la cifosis lumbar en pacientes con mielomeningocele a pesar de altas tasas de complicaciones. Es necesario realizar estudios con mayor número de pacientes y tiempo de seguimiento para evaluar si el uso de tornillos pediculares puede reducir el aflojamiento y la pseudoartrosis.

Descriptores: Mielomeningocele; Tornillos pediculares; Cifosis; cirugía general; Complicaciones postoperatorias.

1. Universidade de São Paulo, Faculdade de Medicina, Instituto de Ortopedia eTraumatologia (IOT-FMUSP), Spine Group, São Paulo, SP, Brazil.

2. Associação de Assistência à Criança Deficiente (AACD), Hospital Abreu Sodré, São Paulo, SP, Brazil. 


\section{INTRODUCTION}

Lumbar kyphosis in patients with myelomeningocele represents a complex deformity of the spine whose correction to maintain vertebral alignment generally depends on surgical treatment. Progressive kyphosis is a result of several factors: incomplete formation of the posterior elements of the spine; imbalance of the paraspinal muscles inserted anterior to the axis vertebra; action without opposition of the psoas muscle and the neurological deficit caused by dysraphism. ${ }^{1-3}$

Lumbar kyphosis occurs in about $8 \%$ to $15 \%$ of patients with myelomeningocele. ${ }^{3-5}$ The resulting gibbosity entails hard-to-heal pressure ulcers and eschars, as well as decreased abdominal volume, respiratory impairment, low back pain and loss of quality of life. 1,3,5 The long lumbar curve includes the sacrum, hindering the act of sitting down and causing these children to tend to fall forwards, unable to sit without support. (Figure 1)

Since the first kyphectomy published by Sharrard, ${ }^{6}$ the surgical technique has undergone constant changes. In 1989, McCarthy et al. $^{7}$ described a technique for fixing the rods in the first sacral foramina, using an "S" or bayonet-shaped casting. Even with some modifications, the most popular series published recently used this technique. ${ }^{8-10}$ The aim of this article is to present the surgical results and complications obtained with the Dunn-McCarthy technique of fixation to the sacrum combined with fixation in the thoracic spine using pedicle screws.

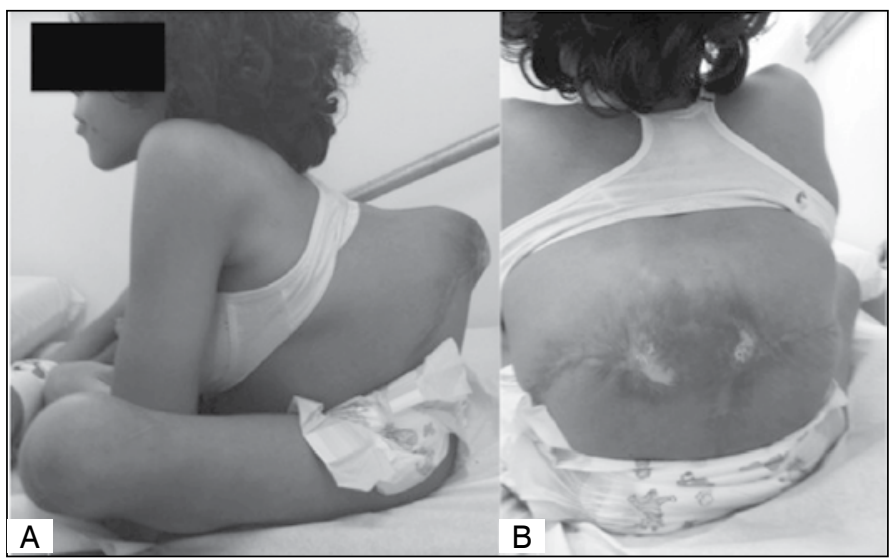

Figure 1. Clinical aspect showing difficulty sitting without support (A) and cutaneous distress at the apex of the deformity (B).

\section{MATERIALS AND METHODS}

Patients operated consecutively at the institution in the year 2012 were selected for inclusion. The study was approved by the Institutional Review Board, under protocol number 814912. A retrospective analysis of the medical records was conducted to collect data relative to surgical indication, spinal tilt and length of hospital stay following the procedure. The information referring to surgery included surgical time, necessary transfusions, number of vertebrae removed and reduction obtained in the postoperative period. The complications relative to postoperative infection and loosening of the synthesis material were also recorded.

All the patients underwent a stringent preoperative assessment. The ventriculoperitoneal valve must be permeable and hydrocephaly compensated. Urinary complications were taken into account, with urine culture testing and the treatment of any infections with at least three days of antibiotic therapy directed by antibiogram. Potential respiratory complications are minimized by means of spirometry in selected patients.

The surgical technique used consists of the modification of the technique described by McCarthy et al. ${ }^{7}$ in which we used fixation with pedicle screws instead of sublaminar ligatures in the thoracic spine. The patient is positioned in prone position on cushions, and the surgeon must avoid compression of the ventriculoperitoneal valve against the ribs or clavicle. The posterior longitudinal incision can pass through the apex of the kyphosis where the skin is more fragile as after the kyphectomy this skin will be redundant and can even be resected. Subperiosteal exposure is then initiated from the normal spinous processes above the deformity. At the apex of the kyphosis, the dissection should be restricted to the region of the transversal processes as there is no lamina protecting the dural sac at this site. Inadvertent injury of the sac should be avoided. The thecal sac is then connected above the level of the planned osteotomy with double sutures, followed by the Valsalva maneuver to check whether there is any CSF leakage. The next stage is the vertebrectomy at the apex of the kyphosis, removing the necessary vertebrae to achieve good apposition of the preserved vertebral bodies. At this point an attempt is made to preserve at least $L 4$ and L5 to allow a sufficient area of bone support and arthrodesis beyond the sacrum.

Osteosynthesis is then performed following the principles described by McCarthy et al.. ${ }^{7}$ The rods are folded in a bayonet shape, where the horizontal arm should have the same thickness as the sacrum and the distal short arm around $3.0 \mathrm{~cm}$ to $3.5 \mathrm{~cm}$. The short arms of the rods are passed rhombically through the S1 foramina where they are located anterior to the sacrum. When the rods are positioned horizontally a lever is formed that ends up reducing the lumbar kyphosis and restoring the sacrum to its original position. (Figure 2)

The upper portion of the rods is then fixed to the thoracic spine

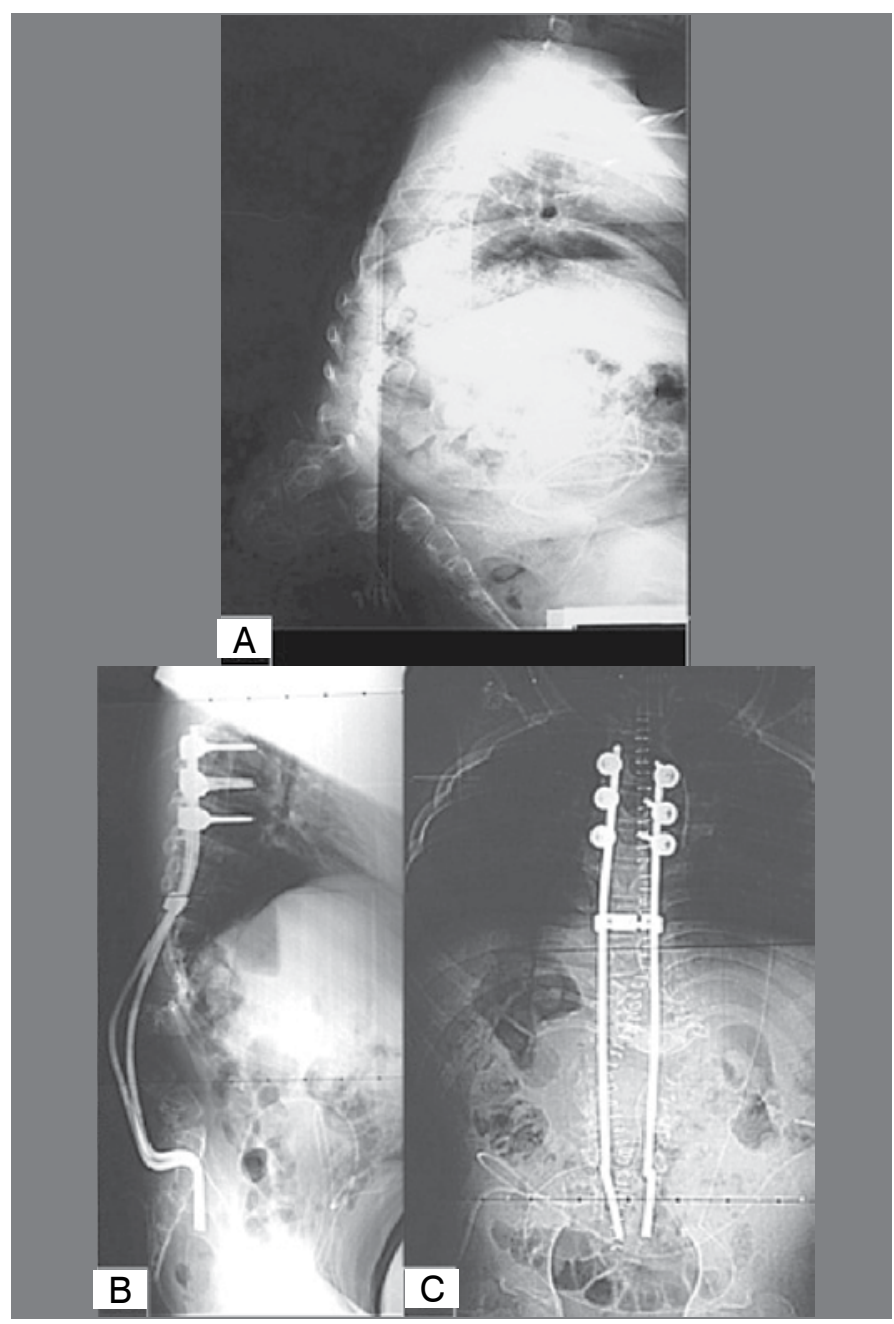

Figure 2. Preoperative radiography of patient 1 showing lumbar kyphosis of $141^{\circ}(A)$. Postoperative radiographies showing correction of kyphosis to $52^{\circ}(\mathrm{B}$ and $\mathrm{C})$. 
using pedicle screws. The resected body provides a good amount of bone graft. Suturing by planes is then performed leaving a subfascial drain. It is not necessary to use immobilization in the postoperative period.

\section{RESULTS}

The results obtained are summarized in Table 1. The average follow-up time of the patients was $7( \pm 4)$ months. The average age of the operated patients was 11 years and 7 months ( \pm 22 months), and the weight was 29.1 ( \pm 12$) \mathrm{Kg}$ at the time of surgery. The mean angle of kyphosis in the preoperative period was $116.3^{\circ}( \pm 37)$, achieving final correction to $62.5^{\circ}( \pm 21)$. In other words, there was a mean reduction of kyphosis of $53.8^{\circ}$ or $46.6 \%$.

An average of 1.5 vertebral bodies had to be removed. The surgical time was $271( \pm 87)$ minutes, requiring the transfusion of $100 \mathrm{ml}( \pm 200)$ of red blood cell concentrate during surgery. The patients remained hospitalized for $10( \pm 8)$ days on average until they were discharged. None of the patients managed to lie in the supine position in the preoperative period. After the procedure, all the patients managed to lie down on their own and to sit without support.

Of the six patients operated, four evolved with postoperative infection, requiring re-hospitalization and surgical cleaning in follow-up. One of these patients had to have the synthesis material removed to control the infection. Another patient had to have the synthesis material removed after one year due to loosening of the rod in the sacrum. There were no complications relative to increased intracranial pressure after dural sac ligature.

\section{DISCUSSION}

The surgical technique for correction of lumbar kyphosis in patients with myelomeningocele has evolved considerably since the first kyphectomy published by Sharrard. ${ }^{6}$ The initial technique required a long period of immobilization and the use of a brace in the postoperative period. In 1987, Heydermann and Gillespie ${ }^{11}$ proposed anterior lumbopelvic fixation, enabling the faster functional recovery of these patients without the need for immobilization with a jacket. In 1989 McCarthy et al. ${ }^{7}$ began to use Luque rods molded in a bayonet shape fixed to the sacral ala as a means of lumbosacral fixation without the need for postoperative immobilization. In 1993 Warner and Fackler ${ }^{12}$ refined this technique, fixing the rods to the first S1 foramen, and demonstrated that it produced a much lower level of complications in comparison to the use of Harrington rods. Fixation to the spine, however, was achieved using sublaminar ligatures

The use of pedicle screws made it possible to improve correction with minimal morbidity in patients with idiopathic scoliosis. ${ }^{13-16}$ The association of pedicle screws with the Dunn-McCarthy technique for correction of hyperkyphosis in myelomeningocele is limited to one reference in literature. ${ }^{9}$ Hwang et al. ${ }^{17}$ recently described two cases where pedicle screws alone were used including for iliac fixation.

The mean reduction from $116.3^{\circ}$ to $62.5^{\circ}$ was considered sufficient for these patients to manage to lie down in the supine position and to sit on their ischia instead of leaning on the posterior sacral lamina. The improvement in the deformity also influences the fact that these patients no longer need wheelchairs with an adapted headrest, and can also sit on normal chairs after the surgery. The mean correction described in the literate ranges from $36 \%$ to $>100 \%$, even creating lordosis in some patients. ${ }^{17}$ The rate of correction achieved in this study was $46.6 \%$. We attribute the relatively high average age of the operated patients (11y and $7 \mathrm{~m}$ ) to the fact that further correction of the curve was not possible, although this has not implied functional loss.

The surgical correction of kyphosis in patients with myelomeningocele is associated with high levels of complications in the literature, which can range between $78 \%$ and $90 \%$ in some series. ${ }^{10,18,19}$ Most complications are related to the surgical wound and need for re-intervention in the postoperative period. Four patients of the six operated in this series $(66.7 \%)$ evolved with postoperative infection and required re-intervention with surgical cleaning. Of these patients, one only had the infection controlled after the removal of the synthesis material in the $7^{\text {th }}$ postoperative month. The thin, poor quality skin that ends up covering the operated area can contribute to continually high rates of infection.

Some studies advocate the performance of the surgery without myelotomy, stating that this reduces the chance of complications related to increased intracranial pressure, CSF leaks and meningitis. ${ }^{20}$ In the cases operated, we did not find any problems relating to ligature of the dural sac and failure of the ventriculoperitoneal valve.

Significant rates of pseudarthrosis and loosing of the synthesis material have been reported in the literature..$^{11,12,19,21}$ One of the patients operated in this series evolved with loosening of the rod in the sacrum and required removal of the synthesis material after one year of follow-up. Although pedicle screws offer better pull-out resistance and better results in idiopathic scoliosis, ${ }^{15,16,22}$ it is still not known whether their use in cases of kyphectomy will reduce the rate of failure of the material.

Table 1. Surgical results and complications.

\begin{tabular}{|c|c|c|c|c|c|c|c|c|c|c|}
\hline Patient & Age & $\begin{array}{l}\text { Follow Up } \\
\text { (months) }\end{array}$ & $\begin{array}{c}\text { Days } \\
\text { hospitalized }\end{array}$ & $\begin{array}{c}\text { Weight } \\
\text { (Kg) }\end{array}$ & $\begin{array}{l}\text { Levels } \\
\text { removed }\end{array}$ & $\begin{array}{l}\Delta \mathrm{t} \text { OT } \\
\text { (min) }\end{array}$ & Pre-op Cobb & Postop Cobb & $\begin{array}{c}\text { Intraop. } \\
\text { transfusions } \\
(\mathrm{mL})\end{array}$ & Complications \\
\hline 1 & $14 y 3 m$ & 12 & 7 & 32 & L2 and L3 & 430 & $146^{\circ}$ & $52^{\circ}$ & 400 & $\begin{array}{l}\text { Postoperative infection. RSM after } \\
12 \text { months due to loosening of the } \\
\text { rod in the sacrum. }\end{array}$ \\
\hline 2 & $10 y$ & 11 & 5 & 22 & L3 & 180 & $100^{\circ}$ & $76^{\circ}$ & 0 & $\begin{array}{l}\text { Postoperative infection. RSM after } 7 \\
\text { months for control of the infection. }\end{array}$ \\
\hline 3 & $9 y 10 m$ & 3 & 6 & 12 & $L 2$ and L3 & 240 & $73^{\circ}$ & $28^{\circ}$ & 0 & \\
\hline 4 & 12 y $9 \mathrm{~m}$ & 3 & 7 & 24 & L1 and L2 & 345 & $175^{\circ}$ & $86^{\circ}$ & 200 & \\
\hline 5 & $8 y 11 \mathrm{~m}$ & 2 & 29 & 50 & L3 & 225 & $76^{\circ}$ & $51^{\circ}$ & 0 & Postoperative infection. \\
\hline 6 & $10 y 11 \mathrm{~m}$ & 2 & 6 & 34,5 & L2 & 210 & $128^{\circ}$ & $82^{\circ}$ & 0 & Postoperative infection. \\
\hline $\begin{array}{c}\text { Mean } \\
\text { (Stand Dev.) }\end{array}$ & $\begin{array}{l}11 \mathrm{y} 1 \mathrm{~m} \\
( \pm 22 \mathrm{~m})\end{array}$ & $\begin{array}{c}7 \pm \\
( \pm 4)\end{array}$ & $\begin{array}{c}10 \\
( \pm 8)\end{array}$ & $\begin{array}{l}29,1 \\
( \pm 12)\end{array}$ & & $\begin{array}{l}271 \\
( \pm 89)\end{array}$ & $\begin{array}{l}116.3^{\circ} \\
\left( \pm 37^{\circ}\right)\end{array}$ & $\begin{array}{l}62.5^{\circ} \\
\left( \pm 21^{\circ}\right)\end{array}$ & $\begin{array}{c}100 \\
( \pm 200)\end{array}$ & \\
\hline
\end{tabular}

y, years; $m$, months; $\Delta t$ OT, operating theater time; RSM, removal of synthesis material; Standard Dev, Standard Deviation. 


\section{CONCLUSION}

The association of the Dunn-McCarthy technique with pedicle screw fixation in the thoracic spine allows excellent functional results after kyphectomy in patients with myelomeningocele. Larger series with a longer follow-up time are necessary to verify whether the rates of complications will be better than those reported in the literature up to that point.

All authors declare no potential conflict of interest concerning this article.

\section{REFERENCES}

1. Martin J Jr, Kumar SJ, Guille JT, Ger D, Gibbs M. Congenital kyphosis in myelomeningocele: results following operative and nonoperative treatment. J Pediatr Orthop. 1994;14(3):323-8.

2. Drennan JC. The role of muscles in the development of human lumbar kyphosis. Dev Med Child Neurol Suppl. 1970;22(Suppl 22):33-8.

3. Hoppenfeld S. Congenital kyphosis in myelomeningocele. J Bone Joint Surg Br. 1967;49(2):276-80.

4. Parsch D, Geiger F, Brocai DR, Lang RD, Carstens C. Surgical management of paralytic scoliosis in myelomeningocele. J Pediatr Orthop B. 2001;10(1):10-7.

5. Lindseth RE, Stelzer L Jr. Vertebral excision for kyphosis in children with myelomeningocele. J Bone Joint Surg Am. 1979;61(5):699-704.

6. Sharrard WJ. Spinal osteotomy for congenital kyphosis in myelomeningocele. J Bone Joint Surg Br. 1968;50(3):466-71.

7. McCarthy RE, Dunn H, McCullough FL. Luque fixation to the sacral ala using the Dunn-McCarthy modification. Spine (Phila Pa 1976). 1989;14(3):281-3.

8. Samagh SP, Cheng I, Elzik M, Kondrashov DG, Rinsky LA. Kyphectomy in the treatment of patients with myelomeningocele. Spine J. 2011;11(3):e5-11.

9. Kocao lu B, Erol B, Akgülle H, Gasimov E, Yalçin S. Combination of luque instrumentation with polyaxial screws in the treatment of myelomeningocele kyphosis. J Spinal Disord Tech. 2008;21(3):199-204.

10. Niall DM, Dowling FE, Fogarty EE, Moore DP, Goldberg C. Kyphectomy in children with myelomeningocele: a long-term outcome study. J Pediatr Orthop. 2004;24(1):37-44.

11. Heydemann JS, Gillespie R. Management of myelomeningocele kyphosis in the older child by kyphectomy and segmental spinal instrumentation. Spine (Phila Pa 1976). 1987:12(1):37-41.

12. Warner WC Jr, Fackler CD. Comparison of two instrumentation techniques in treatment of lumbar kyphosis in myelodysplasia. J Pediatr Orthop. 1993;13(6):704-8.

13. Kim YJ, Lenke LG, Cho SK, Bridwell KH, Sides B, Blanke K. Comparative analysis of pedi- cle screw versus hook instrumentation in posterior spinal fusion of adolescent idiopathic scoliosis. Spine (Phila Pa 1976). 2004;29(18):2040-8.

14. Lowenstein JE, Matsumoto H, Vitale MG, Weidenbaum M, Gomez JA, Lee FY, et al. Coronal and sagittal plane correction in adolescent idiopathic scoliosis: a comparison between all pedicle screw versus hybrid thoracic hook lumbar screw constructs. Spine (Phila Pa 1976). 2007;32(4):448-52.

15. Rose PS, Lenke LG, Bridwell KH, Mulconrey DS, Cronen GA, Buchowski JM, et al. Pedicle screw instrumentation for adult idiopathic scoliosis: an improvement over hook/hybrid fixation. Spine (Phila Pa 1976). 2009;34(8):852-7.

16. Suk SI, Lee SM, Chung ER, Kim JH, Kim SS. Selective thoracic fusion with segmental pedicle screw fixation in the treatment of thoracic idiopathic scoliosis: more than 5-year follow-up. Spine (Phila Pa 1976). 2005;30(14):1602-9.

17. Hwang SW, Thomas JG, Blumberg TJ, Whitehead WE, Curry DJ, Dauser RC, et al. Kyphectomy in patients with myelomeningocele treated with pedicle screw-only constructs: case reports and review. J Neurosurg Pediatr. 2011;8(1):63-70.

18. Ko AL, Song K, Ellenbogen RG, Avellino AM. Retrospective review of multilevel spinal fusion combined with spinal cord transection for treatment of kyphoscoliosis in pediatric myelomeningocele patients. Spine (Phila Pa 1976). 2007;32(22):2493-501.

19. McMaster MJ. The long-term results of kyphectomy and spinal stabilization in children with myelomeningocele. Spine (Phila Pa 1976). 1988;13(4):417-24.

20. Nolden MT, Sarwark JF, Vora A, Grayhack JJ. A kyphectomy technique with reduced perioperative morbidity for myelomeningocele kyphosis. Spine (Phila Pa 1976). 2002;27(16):1807-13

21. Fürderer $S, \operatorname{Hopf} C$, Schwarz M, Voth D. Orthopedic and neurosurgical treatment of severe kyphosis in myelomeningocele. Neurosurg Rev. 1999;22(1):45-9.

22. Sell P, Collins M, Dove J. Pedicle screws: axial pull-out strength in the lumbar spine. Spine (Phila Pa 1976). 1988;13(9):1075-6. 